\title{
Access to EEOC Files Concerning Private Employers
}

Information concerning private employment practices gathered by the Equal Employment Opportunity Commission is often sought by individuals who wish to sue for alleged employment discrimination. Such information is also sought by employers to use in defending against discrimination suits. Public access to the information is strictly limited by statute; the statute, however, leaves in doubt the extent to which employees and employers are to be treated as members of the public for the purpose of the access provisions.

Section 709(e) of Title VII of the Civil Rights Act of 1964 prohibits the EEOC from making public any information it has obtained pursuant to its investigative authority prior to the institution of a proceeding involving such information. ${ }^{1}$ Similarly, with respect to conciliation proceedings section $706(\mathrm{~b})$ provides that "[c]harges shall not be made public by the Commission . . . . Nothing said or done during and as part of . . . [conciliation efforts] may be made public by the Commission . . . or used as evidence in a subsequent proceeding without the written consent of the persons concerned."'2 The EEOC has consistently asserted that the concerned employees and employers are not members of the "public" within the meaning of the provisions. ${ }^{3}$ The Commission has exercised its claimed discretion over release of the information by routinely releasing all relevant investigative information, and occasionally releasing conciliation information, to aggrieved employees. It has refused to provide such information to employers. ${ }^{4}$ The federal courts have split on the issue of the propriety of this practice. ${ }^{5}$

This comment reviews the arguments based on the wording, legislative history, administrative interpretation, and policies of the statute. It concludes that employees and, with some exceptions, employers should be treated as members of the public, and thus should be denied special access to the files. Finally, in cases in which some disclosure is permissible, the comment considers the difficulties in defining the proper scope of disclosure.

142 U.S.C. $\& 2000 \mathrm{e}-8(\mathrm{e})(1976)$.

2 Id. $\S 2000 \mathrm{e}-5(\mathrm{~b})$.

3 See 29 C.F.R. \& 1601.22 (1978); EEOC CoMPL. MAN. (CCH) Лी 1781, 1785 (1977).

- EEOC Compl. MaN. (CCH) I 1785 (1977).

s Compare Burlington N., Inc. v. EEOC, 582 F.2d 1097 (7th Cir. 1978), cert. denied, 99 S. Ct. 1267 (1979), Sears, Roebuck \& Co. v. EEOC, 581 F.2d 941 (D.C. Cir. 1978), and Associated Dry Goods Corp. v. EEOC, 454 F. Supp. 387 (E.D. Va. 1978) with H. Kessler \& Co. v. EEOC, 472 F.2d 1147 (5th Cir.) (en banc), cert. denied, 412 U.S. 939 (1973). 


\section{BACKGROUND}

There are two categories of information contained in the EEOC's files: investigatory information and conciliation information. The former is obtained by the EEOC by right under its subpoena powers, ${ }^{6}$ and may be revealed to the public only after charges are filed in court. ${ }^{7}$ The latter is obtained by the Commission by the voluntary cooperation of employers, during the course of informal negotiations. It is permanently protected by statute from public disclosure. ${ }^{8}$

As amended in 1972," Title VII contemplates a two-step process. First, upon receiving complaints of discrimination against an employer, the EEOC is to conduct an investigation to determine whether probable cause for the charge of discrimination exists. ${ }^{10}$ For this purpose, the EEOC was given wide subpoena power, enabling it to obtain data concerning the general employment practices of the employer as well as the particular employment decisions challenged. ${ }^{11}$ On finding probable cause, the EEOC is to enter into negotiations with the employer concerning possible remedies. ${ }^{12}$ If the negotiations fail to reach a satisfactory solution, the EEOC is empowered to file suit. ${ }^{13}$ Aggrieved employees also have a right to file suit 180 days after filing a complaint with the Commission if no conciliation agreement has been reached, or within 90 days after the Commission gives notice of its failure to negotiate the settlement and its decision not to file suit. ${ }^{14}$

- In practice the EEOC has generally employed informal investigative methods rather than its formal subpoena power. B. Schiei \& P. Grossman, Employment Discrimination Law 779 (1976).

742 U.S.C. $\S 2000 \mathrm{e}-8(\mathrm{e})(1976)$.

\& Id. \& 2000e-5(b) (1976).

- Title VII was substantially amended by the Equal Employment Opportunity Act of 1972, Pub. L. No. 92-261, 86 Stat. 103 (1972) (codified in scattered sections of 42 U.S.C. (1976)). See Hart \& Sape, Title VII Reconsidered: The Equal Employment Opportunity Act of 1972, 40 Geo. WaSh. L. REv. 824 (1975).

1042 U.S.C. $\S 2000 \mathrm{e}-5(\mathrm{~b})$ (1976). In many states, part of the EEOC's function is performed by a state agency. See id. $\$ 2000 \mathrm{e}-5(\mathrm{e})$. For purposes of this comment, the states' role in Title VII enforcement is disregarded.

"Id. \& 2000e-8(a) (1976). See, e.g., Motorola, Inc. v. McClain, 484 F.2d 1339 (7th Cir. 1973), cert. denied, 416 U.S. 936 (1974).

1242 U.S.C. $\$ 2000 \mathrm{e}-5(\mathrm{~b})$ (1976). See generally B. Schlet \& P. Grossman, supra note 6, at 778-802.

is 42 U.S.C. $\S 2000$-5(f) (1976). Aggrieved employees have a right to intervene in such suits. When the employer is a government, governmental agency, or political subdivision, then any suit must be brought by the Justice Department. Id. Aggrieved employees have a right to intervene in such suits also. The EEOC may, in addition, bring pattern-or-practice suits against employers in cases of systematic discrimination.

14 Id. \&2000e-5(f). 
In practice, this procedure has not proven effective..$^{15}$ The enormous backlog of cases before the EEOC ${ }^{18}$ has made prompt independent investigation of all discrimination charges impracticable. The Commission has therefore replaced the two-step statutory process with routine use of "predetermination settlement discussions," conducted before investigation of the charges. ${ }^{17}$ The object of the predetermination settlement discussions is to reach an agreement without having to undertake an investigation. If negotiations occur after investigation and determination of probable cause, the resulting agreement is called "conciliation" rather than "settlement," but functionally the two types of agreement are the same. ${ }^{18}$ The result of this new procedure is to integrate the EEOC's litigation, investigation, and conciliation functions. ${ }^{10}$ Much of the information that formerly would be obtained through investigation is now supplied by employers during negotiation. The strict dichotomy between investigative files and conciliation files has thus broken down, presenting difficult problems of interpretation of the confidentiality provisions, which are predicated on that dichotomy. ${ }^{20}$

An employee may seek information accumulated by the EEOC for a variety of reasons. If he is deciding whether to file suit, he might consider obtaining the EEOC files as the cheapest and easiest means of evaluating the likelihood of success on his claim, or of convincing an attorney to take his case. Although once he has filed suit, the statute permits him to receive access to the investigatory file, he might also seek access to the conciliation file in order to bolster his case. Moreover, if the EEOC has negotiated a settlement with the employer, the individual employee might seek access to the information held by the EEOC in order to decide whether to accept the settlement rather than file suit on his own. Procedurally, it is

15 For a sharp criticism of the performance of the EEOC, see Belton, A Comparative Review of Public and Private Enforcement of Title VII of the Civil Rights Act of 1964, 31 VAND. L. REv. 905 (1978). See also GAO, EQUAL EMPLOYMENT OPPORTUNITY Commission Has Made Limited Progress in Eliminating Employment Discrimination (1976).

"As of July, 1977, the EEOC had a backlog of approximately 130,000 cases. Oversight Hearings on Equal Employment Opportunities Before the Subcomm. on Employment Opportunities of the House Comm. on Education and Labor, 95th Cong., 1st Sess. 11 (1977) (statement of Commissioner Eleanor Holmes Norton) [hereinafter cited as Oversight Hearings].

1729 C.F.R. $\$ 1601.20$ (1978). See B. Schlet \& P. Grossman, supra note 6, at 776; Oversight Hearings, supra note 16, at 9-10, 13-14 (testimony of Commissioner Eleanor Holmes Norton).

18 Compare B. Schlei \& P. Grossman, supra note 6, at 776, with id. at 807-08. As a practical matter, it may be easier for the employer to reach agreement in the earlier stage. Id. at 810 .

1 See Oversight Hearings, supra note 16, at 13.

20 See, e.g., Parker v. EEOC, 534 F.2d 977 (D.C. Cir. 1976). 
not difficult for the employee to obtain the information he seeks: the EEOC will generally honor any request or subpoena for information in its files. ${ }^{21}$ Unless the employer files suit to enjoin disclosure of the information, the employee will generally receive it without further complication. Most litigation on the issue, therefore, takes the form of a suit by an employer against the EEOC asking for an injunction against disclosure..$^{22}$

In some instances, however, the employer seeks access to the EEOC files, by request, subpoena, discovery, or Freedom of Information Act $^{23}$ demand. In these cases the EEOC generally resists disclosure. ${ }^{24}$ Litigation generally takes the form of a discovery motion, or more commonly, an FOIA suit. Regardless of the procedural posture of the litigation, the legal issue remains the same. Suits to compel disclosure will be answered by the claim that the information is exempted by the FOIA's third exception, that it is: "specifically exempted from disclosure by statute." ${ }^{25}$ Although filed under the Administrative Procedure Act, suits to prevent disclosure will be predicated directly on Title VII's confidentiality provisions. ${ }^{26}$ In both suits, the result will be governed by the reading given to Title VII.

21 EEOC CoMpl. MAN. (CCH) ๆ'1785 (1977). In the wake of Sears and Burlington Northern, the EEOC offices in the District of Columbia and Seventh Circuits have stopped releasing files to charging parties that have not filed suit. Other offices have stopped releasing information from consolidated files, except for release of information directly related to individual charges that have been sued upon. Id. $₫ 1792$.

22 Employers may sue under the Administrative Procedure Act, 5 U.S.C. $\S 702$ (1976), which provides that a "person suffering legal wrong because of agency action, or adversely affected or aggrieved by agency action . . . , is entitled to judicial review thereof." The substantive basis for challenging the agency's decision to disclose information to aggrieved employees is found in the confidentiality provisions of Title VII. Employers have no cause of action based directly on the Freedom of Information Act exceptions, 5 U.S.C. $\S 552(\mathrm{~b})$ (1976). Chrysler Corp. v. Brown, 99 S.'Ct. 1705 (1979).

z 5 U.S.C. $\$ 552(a)(4)(B)(1976) ;$ see Charlotte-Mecklenburg Hosp. Auth. v. Perry, 571 F.2d 195 (4th Cir. 1978); EEOC v. St. Francis Community Hosp., 70 F.R.D. 592 (D.S.C. 1976); EEOC v. Georgia Pac. Corp., 11 F.E.P. 722 (D. Ore. 1975); EEOC v. Los Alamos Contractors, Inc., 382 F. Supp. 1373 (D.N.M. 1974).

${ }^{21}$ See the cases discussed in text and notes at notes 106-113 infra; EEOC CoMpl. MAN. (CCH) \ 1785 (1977).

${ }^{25} 5$ U.S.C. $\$ 552$ (b)(3) (1976). See generally K. Davis, Administrative Law Treatise $\S$ 5:31, at 393 (1978). Portions of the EEOC files, written or compiled for the internal use of the agency or for use in cooperation with other agencies, may fall within the fifth exemption, "inter-agency or intra-agency memorandums." 5 U.S.C. \& 552(b)(5) (1976). See EEOC Compl. MAN. (CCH) \1788(d) (1977) (instructions to remove intra-agency memoranda before disclosure). The seventh exemption, which applies to some investigatory records of law enforcement agencies, applies only in certain restrictive circumstances. See 5 U.S.C. $§ 552(\mathrm{~b})(7)$ (1976); EEOC CoMpl. MAN. (CCH) I 1785(b) (1977) (removal of statements and identification of anonymous witnesses from file before disclosure). For purposes of this comment, only the third exemption will be considered in detail.

see note 22 supra. 
Three federal courts of appeals have considered the question whether aggrieved employees are members of the public for purposes of Title VII's confidentiality provisions. The Fifth Circuit, in H. Kessler \& Co. v. EEOC, ${ }^{27}$ held that an aggrieved employee and his attorney could obtain investigative information prior to filing suit. The court emphasized the "limited form of disclosure"28 involved in the case: the investigative file contained only information pertaining to the one aggrieved employee's case, and the parties were forbidden by the court to disseminate the information to the wider public. Since the Kessler decision was ultimately an interpretation of the word "public,"29 however, the federal courts have subsequently viewed its holding as exempting aggrieved employees from the confidentiality provisions of Title VII. ${ }^{30}$ Five years later, in Sears, Roebuck, \& Co. v. EEOC, ${ }^{31}$ the District of Columbia Circuit rejected the Kessler reasoning, and denied access by Sears employees to conciliation and investigative information until after they had filed suit. In Burlington Northern, Inc. v. EEOC, ${ }^{32}$ the Seventh Circuit agreed with the Sears construction of Title VII, and further held that after filing suit, a charging party could obtain only such investigatory information as is "directly relevant" 33 to his particular claim. By denying certiorari in Burlington, ${ }^{34}$ the Supreme Court declined to resolve the conflicting precedents. ${ }^{35}$

${ }^{27} 472$ F.2d 1147 (5th Cir. 1972) (en banc), cert. denied, 412 U.S. 939 (1973).

23 Id. at 1149 .

Id. at $1150,1151$.

* Charlotte-Mecklenburg Hosp. Auth. v. Perry, 571 F.2d 195 (4th Cir. 1978) (not contested that employer was not within the confidentiality provisions of Title VII); Sears, Roebuck \& Co. v. EEOC, 435 F. Supp. 751 (D.D.C. 1977), aff'd in part, rev'd in part, 581 F.2d 941 (D.C. Cir. 1978); National Elec. Contractors Ass'n v. Walsh, 12 Empl. Prac. Dec. T11,116 (D.D.C. 1976). See also EEOC CoMPL. MAN. (CCH) II 1781 (1977) (granting charging parties access to investigative files is not "making public" within the meaning of section 709(e)).

31 581 F.2d 941 (D.C. Cir. 1978).

32 582 F.2d 1097 (7th Cir. 1978), cert. denied, 99 S. Ct. 1267 (1979).

Id. at 1101. The District Court for the Eastern District of Virginia also adopted Sears's approach in Associated Dry Goods Corp. v. EEOC, 454 F. Supp. 387 (1978).

s 99 S. Ct. 1267 (1979).

3s It might be possible to distinguish Kessler from Sears and Burlington Northern on the ground that Kessler concerned a single employee of a small business: the disclosure was necessarily much more limited than in the nationwide investigations of Sears and Burlington Northern. See Sears, Roebuck \& Co. v. EEOC, 581 F.2d 941, 947 (D.C. Cir. 1978) (attempting to distinguish Kessler); Associated Dry Goods Corp..v. EEOC, 454 F. Supp. 387 (1978) (same). However different the cases may be on policy grounds, it is impossible to find a distinction between small employers and large employers in the statutory language.

It might be suggested that Kessler is no longer good law. The decision relied in its policy analysis on the Title VII provisions replaced by the 1972 amendments. See Sears, 581 F.2d at 498; Associated Dry Goods, 454 F. Supp. at 391. The Fifth Circuit has not reversed its position, however, and there is no necessary reason for it to do so. To the extent that private 


\section{The Statute}

\section{A. Statutory Language}

The starting point in analyzing the meaning of the confidentiality provisions of Title VII is the statute itself. ${ }^{36}$ Unfortunately, the language does not provide clear support for any one interpretation; perhaps this is why only one court ${ }^{37}$ has seriously attempted to defend its reasoning on the basis of the statutory language. The word "public" is nowhere defined in the statute. Its use in the phrase "to make public"-found in both sections 706(b) and 709(e)-is susceptible to a variety of interpretations. It could be read as a prohibition of mass publication by the EEOC of charges and information. Such a prohibition would not necessarily extend to an employer or an employee since, as parties to the controversy, they would be entitled to be informed about the charges against them or the investigation and conciliation on their behalf. The statute could also be read as a strict prohibition of disclosure of information to anyone outside the government. A middle position might also be found: "to make public" might be to disclose to anyone not specifically involved with the information. Thus, employers and employees would generally be protected from broad disclosure of information they supply to the EEOC. The EEOC would serve as a neutral arbitrator, protecting the confidentiality of both sides' submissions.

The Fifth Circuit in H. Kessler \& Co. v. EEOC ${ }^{38}$ adopted the most relaxed interpretation of the confidentiality provisions. The court observed that the word "public" is used twice in section 706(b) ${ }^{39}$ First, the statute provides that "charges shall not be made public." Second, in the provision under scrutiny in the case, it provides that "[n]othing said or done during and as a part of such endeavors [conciliation negotiations] may be made public without the written consent of the persons concerned." 40 The Kessler court

\footnotetext{
lawsuits remain an important mode of enforcement of Title VII, some courts may find the policy basis of Kessler-the need to promote such lawsuits-persuasive.

34 Frankfurter, Some Reflections on the Reading of Statutes, 47 Colum. L. REv. 527, 535 (1947).

${ }^{37}$ H. Kessler \& Co. v. EEOC, 472 F.2d 1147 (5th Cir.) (en banc), cert. denied, 412 U.S. 939 (1973).

Id.

3s Id. at 1151.

4 Although the 1972 amendments took effect nine months before the Kessler decision, the court interpreted an earlier version of section 706(b), which prohibited disclosure of conciliation information without the consent "of the parties." Civil Rights Act of 1964, Title VII, Section 706(a), 78 Stat. 259 (1964) (current version at 42 U.S.C. $\$ 2000 \mathrm{e}-5$ (b) (1976)). It is possible that "of persons concerned" is a narrower term than "the parties." Under either phrasing, however, the employer's consent would be required.
} 
reasoned that since employers must be informed of charges made against them, they cannot be considered part of the "public" for purposes of the statute. ${ }^{11}$ Moreover, since the "persons concerned" must grant permission for conciliation information to be "made public," the statute seems to distinguish between employers and employees on the one hand and the public on the other. ${ }^{42}$

This reading of the statute is plausible, but it is not ultimately persuasive. Although charges must be revealed to employers, there is every reason to believe that the employer will protect the charges from further dissemination. In contrast, disclosure of investigatory or conciliation information to aggrieved employees invites wider dissemination. From the point of view of the employer, the employee must be viewed as a part of the "public," and vice versa. Moreover, the clause "charges shall not be made public" is closely followed in section 706(b) by a prohibition against using conciliation information as evidence in any subsequent proceeding. ${ }^{43}$ Since Congress prevented the EEOC from presenting the information to a court in prosecuting a lawsuit, it is highly unlikely that it intended to permit the Commission to disclose the same information to aggrieved employees to aid them in their own court presentations.

The language of section 709(e) provides even less guidance. It sets up no arguable distinction between persons concerned and the public. Although its prohibition against making the investigatory information public "in any manner whatsoever" might be interpreted to forbid disclosure to anyone, ${ }^{44}$ it might also be read to apply only to the method of publication. ${ }^{45}$ Even if aggrieved employees are excluded from the definition of "public" in section 709(e), however, the "in any manner whatsoever" language may be read as prohibiting disclosure to them on the ground that the information might be indirectly disseminated to the general public by the employees.

\section{B. Legislative History}

The legislative history of the confidentiality provisions is similarly inconclusive. Again, the Fifth Circuit ${ }^{46}$ is the only court to attempt to derive much support from it, ${ }^{47}$ although the court had

4472 F.2d at 1151.

42 Id.

is 42 U.S.C. $\S 2000 \mathrm{e}-5$ (b) (1976).

4472 F.2d at 1152-53 (Coleman, J., dissenting).

is Id. at $1151 \mathrm{n} .2$ (majority opinion).

"Id.

${ }^{47}$ The District of Columbia Circuit said: "[A]lthough the legislative history is sparse, we believe that Congress' intention in enacting $\$ 709(\mathrm{e})$, viewed in light of the well- 
to concede that the legislative history was "scant" 48 and provided only "slender wisps" 40 of support. The most relevant item in the legislative history is a remark by Senator Humphrey, who introduced the confidentiality provisions as an amendment:

Provisions preserving the confidentiality of Commission procedures have been added to sections 706(a) and 709(e). . . .

It should be noted that this is a ban on publicizing and not on such disclosure as is necessary to the carrying out of the Commission's duties under the statute. Obviously, the proper conduct of an investigation would ordinarily require that the witness be informed that a charge had been filed and often that certain evidence had been received. Such disclosure would be proper. The amendment is not intended to hamper Commission investigations or proper cooperation with other State and Federal agencies, but rather is aimed at the making available to the general public of unproven charges. ${ }^{50}$

The Kessler court concluded that Senator Humphrey's description of the clause as "a ban on 'publicizing' aimed at avoiding making charges available to the 'general public' " implied that the ban was not intended to apply to parties to the controversy. ${ }^{51}$ The quoted remarks, however, apparently pertain to section 706(a)'s prohibition on making public charges of discrimination. Of course, the charging employee and the charged employer have access to such charges.52 For purposes of the confidentiality provisions pertaining to investigatory and conciliation information, however, the considerations are entirely different. Unlike charges, the substance of which must form the basis of fair negotiation or litigation, the investigatory and conciliation files are evidentiary in nature and may be produced with the cooperation of the employer. Neither Senator Humphrey nor any other congressman discussed the scope of these provisions. Senator Humphrey's interpretation of another, different provision should not govern their interpretation.

established practice throughout the government, was to forbid disclosure of sensitive data to any persons outside the government." Sears, Roebuck \& Co. v. EEOC, 581 F.2d 941, 947 (D.C. Cir. 1978).

47 F.2d at 1150 .

"Id. at 1151.

so 110 Cong. REc. 12723 (1964).

si 472 F.2d at 1150 .

32 Although the Commission previously withheld charges from the employer in order to protect the charging employee from retaliation, the practice is now to release the charge to the employer as soon as possible in order to facilitate early settlement of the dispute. EEOC Compl. MAN. (CCH) IT 784, 794 (1979). 
The Kessler court also relied on the 1972 rejection of an amendment that would have prohibited disclosure of certain records required to be kept by employers to anyone "except to Congress or any committee thereof, or to a governmental agency, or in the presentation of any case or proceeding before any court or grand jury."53 The proposed amendment was deleted without comment by the conference committee. The Kessler court argued that the deletion of this proposed amendment shows that Congress considered extending the definition of "public" to include employers and employees but declined to do so. ${ }^{54}$ The proposed subsection did not, however, use the word "public," nor did it relate in any way to investigatory or conciliation information. ${ }^{55}$ It would have applied solely to routine recordkeeping requirements. It is therefore difficult to draw an inference that Congress intended to exclude employers and employees from the definition of "public" in other separate sections of the statute.

\section{Administrative Interpretation}

The EEOC has interpreted section 709(e) to permit release of investigative information to aggrieved employees:

Neither a charge, nor information obtained pursuant to $\S$ 709(a) of Title VII . . . shall be made matters of public information by the Commission prior to the institution of any proceedings under this title involving such charges or information. This provision does not apply to such earlier disclosures to the charging party where disclosure is deemed necessary for securing appropriate relief. ${ }^{56}$

The Commission is more equivocal with respect to conciliation information. The applicable regulation states that such information may not "be made a matter of public information"; 57 it contains no specific exception for release to employees.

The interpretation by an agency of the statute under which it operates is accorded great deference by the courts. ${ }^{58}$ As Professor Jaffe has said, "Where the judges are themselves convinced that a certain reading, or application, of the statute is the correct-or the only faithful-reading or application, they should intervene and so

ss S. REP. No. 415, 92d Cong., 1st Sess. 67 (1971).

st 472 F.2d at $1150-51$.

ss See 42 U.S.C. $\$ 2000 \mathrm{e}-8$ (c) (1976).

s6 29 C.F.R. $\$ 1601.22$ (1978).

57 Id. $\S 1601.26$.

ss Board of Governors v. Agnew, 329 U.S. 441, 450 (1947) (Rutledge, J., concurring); Gray v. Powell, 314 U.S. 402 (1941). 
declare. Where the result of their study leaves them without a definite preference, they can and often should abstain if the agency's preference is 'reasonable.' "\$59 Deference is especially appropriate in applying the statutory language to a particular set of facts, ${ }^{60}$ or in making technical judgments. ${ }^{\circ 1}$ As the Supreme Court has emphasized, however, this deference "must have limits" and should be superceded when necessary to effectuate the congressional intent. ${ }^{62}$

Based on these principles, the EEOC's interpretation of the word "public" in the confidentiality provisions of Title VII, although persuasive, is not dispositive. ${ }^{63}$ The inclusion of employers and employees within the terms in no way depends on the particular facts in the case: once a definition is decided upon, it is not difficult to apply to factual situations. Moreover, the decision does not involve agency expertise. Although the ultimate decision regarding the meaning of the term must be made on policy grounds, with respect to which the EEOC is presumptively expert, the essential balancing of disclosure against nondisclosure and private lawsuits against EEOC negotiation has already been made by Congress. Where Congress has chosen to restrict the discretion of the agency to disclose information, a court rather than the agency is better equipped and disposed to. effectuate that intent. None of the courts to consider the question have deemed it necessary to defer to the EEOC's judgment; ${ }^{64}$ each considered the question of statutory interpretation de novo.

\section{Statutory Policy}

In view of the inconclusiveness of the statutory language and legislative history, it is necessary to examine the EEOC's reading of the confidentiality provisions in the light of the policy of Title VII. Briefly stated, Title VII provides a mechanism for redressing unlaw-

39 L. Jaffe, Judiclal Control of Administrative Action 572 (1965).

so See, e.g., NLRB v. Hearst Publications, Inc., 322 U.S. 111, 130-31 (1944) (newsboys held to be "employees" based on NLRB determination).

61 See, e.g., NLRB v. Highland Park Co., 341 U.S. 322, 327 (1951) (Frankfurter, J., dissenting).

s2 Espinoza v. Farah Mfg. Co., 414 U.S. 86, 94 (1973).

63 The EEOC's definition is entitled to less than the usual deference because its decision to release information to employees, but not to employers, see text and notes at notes 70-113 infra, is partial and arbitrary.

"The Kessler court reached an independent determination that the EEOC's position "constitutes an accurate assessment of the relevant law." 472 F.2d at 1149. The Sears court, 581 F.2d at 946 n.5, and the Burlington Northern court, 582 F.2d at 1099, both rejected the EEOC interpretation without apparent reluctance. 
ful discrimination ${ }^{65}$ in employment. The main instrument of Title VII is the process of conciliation and negotiation between the EEOC and the private employer. The conciliation process is supplemented by private lawsuits by aggrieved employees and suits by the Commission or Attorney General in cases when negotiation fails. To a great extent, however, private lawsuits may interfere with the conciliation process. Congressional intent in using the word "public" in the confidentiality provisions may best be discerned from the effect of disclosure to aggrieved employees on the enforcement of Title VII.

\section{A. The Case for Disclosure to Aggrieved Employees}

The argument in favor of disclosing all available information to aggrieved employees is straightforward: disclosure will facilitate the prosecution of meritorious private actions. More individual employees will receive redress; more employers will be deterred from unlawful discriminatory behavior. ${ }^{\circ 8}$ Access to the EEOC file is tantamount to free discovery. Often it is tantamount to a packaged lawsuit. ${ }^{67}$ The conclusion that disclosure is desirable is buttressed by the typically impecunious position of the Title VII plaintiff. A victim of employment discrimination often will not have the financial resources to support a lawsuit; without substantial information about his claim, he may be unable to obtain counsel on a contingent-fee basis. Granting access to the EEOC files might substantially reduce the prospect that the victim's poverty will stand between him and judicial redress. ${ }^{88}$

In addition, release of information in the EEOC files may be necessary so that an aggrieved employee who has filed a charge with the Commission can make an intelligent decision on whether to accept a negotiated settlement. In one sense, the employee is in a position no different from any potential plaintiff contemplating a settlement offer. He no more deserves government help in making up his mind than any potential litigant. On the other hand, the litigation strategy of the Title VII plaintiff may have been upset by

is The unlawful practices are defined in 42 U.S.C. $\S 2000 \mathrm{e}-2$ (1976).

c See Belton, supra note 15 (arguing that private lawsuits have been the most important means of enforcing Title VII).

" In Sears, for example, the EEOC proposed to mail to aggrieved employees a 250-page report, summarizing data obtained from Sears in investigation and conciliation, and containing interpretation by the Commission of the factual basis for its finding of reasonable cause. 581 F.2d at 945. It should be noted, however, that the EEOC file, at least in part, may be inadmissible at trial. Gillin v. Federal Paper Board Co., 479 F.2d 97, 99-100 (2d Cir. 1973); Kinsey v. Legg, Mason \& Co., 10 Fair Empl. Prac. Cas. 1013, 1015 (D.D.C. 1974).

"s This was the main policy basis for the Fifth Circuit's decision in Kessler. 472 F.2d at 1151-52. 
governmental action. The EEOC has negotiated a settlement; he has only 90 days to decide whether to file suit. ${ }^{69}$ Since the EEOC has placed him in this cramped position, it seems reasonable that the EEOC should also supply him with the information necessary to make his decision within the stipulated time period. To the extent, then, that Title VII enforcement is enhanced by private lawsuits and by individuated decisions on the value of EEOCnegotiated settlements, disclosure of EEOC file information to aggrieved employees is desirable.

\section{B. The Case Against Disclosure to Aggrieved Employees}

From its inception in 1965, Title VII enforcement has depended principally upon informal conciliation and negotiation between the EEOC and the private employer. ${ }^{70}$ This emphasis was reenforced by the 1972 amendments to Title VII, ${ }^{71}$ which granted the EEOC the power to file suits against employers and prohibited aggrieved employees from filing suit until 180 days after filing charges with the Commission. The purpose of these amendments was to give the Commission an unfettered opportunity to investigate and settle the charges. ${ }^{72}$ Congress even considered abolishing the private Title VII lawsuit altogether, ${ }^{73}$ but instead retained it to provide an "escape from the administrative quagmire" process charges with acceptable speed. The conference committee expressed the hope that "the vast majority of complaints will be handled through the offices of the EEOC"; they viewed the private lawsuit as an "exception and not the rule."75

The practical reasons for this policy have been restated recently by the Chairman of the EEOC, Eleanor Holmes Norton, testifying before a congressional oversight committee:

With a filing rate this year [1977] projected at more than 80,000 charges, no formal process can avoid being swamped. Therefore, if the system is to function, it must use resolution techniques which do not require exhausting the whole process.

42 U.S.C. \& 2000e-5(f) (1976).

${ }^{70}$ Alexander v. Gardner-Denver Co., 415 U.S. 36, 44 (1974). But see Belton, supra note 15.

"See note 9 supra.

72 S. REP. No. 415, 92d Cong., 1st Sess. 24 (1971).

${ }^{23}$ The proposed amendment, No. 877 to S. 2515 , was defeated by a vote of 33 to 33.118 Cong. Rec. 3373 (1972).

$"$ H. REP. No. 238, 92d Cong., 1st Sess. 12 (1971), reprinted in [1972] U.S. Code CoNG. \& AD. News 2147-48.

75118 Cong. Rec. 4942 (1972). 
Swamping of the process harms complainants and respondents alike and threatens the very existence of charge processing as a system. ${ }^{76}$

She concluded that "[a]ll of our procedures are being shaped with the objective of encouraging prompt and fair conciliations." Both Congress and the EEOC agree that the elimination of discrimination in the nation's workplaces is more effectively achieved by broad and systematic agreements negotiated on an informal basis than by the prosecution of random individual suits.

Disclosure of conciliation information to aggrieved employees and disclosure of investigative information to them before suit is filed have different effects on the conciliation process. In both instances, however, such disclosure seriously hampers the conciliation effort. In view of the primacy of conciliation over the private lawsuit, therefore, it must be concluded that this effect outweighs the advantages of disclosure to the individual aggrieved employee.

Also significant is that the 1972 amendments alleviated one of the impediments the potential Title VII plaintiff formerly faced in obtaining an attorney for his lawsuit. The time allowed an aggrieved employee to file suit ${ }^{78}$ after receiving notice that the Commission had failed to reach a settlement and was not going to file suit was increased from 30 to 90 days, ${ }^{79}$ thus eliminating a problem that convinced the Kessler court that the potential plaintiff needed access to EEOC files in order to beat the deadline ${ }^{80}$ In addition, the 1964 Act already provided for attorney's fees for prevailing parties, ${ }^{81}$ for court-appointed attornies, ${ }^{82}$ and for waiver of court fees, costs, and security. ${ }^{83}$ The effect of this change is to make it much easier for an aggrieved employee to file a lawsuit if he desires; he no longer needs the additional benefit of access to EEOC files. ${ }^{84}$

1. Effect of Disclosure of Conciliation Information. The employer enters into conciliation negotiations with the EEOC for much

76 Oversight Hearings, supra note 16, at 8 (statement of Commissioner Eleanor Holmes Norton).

"Id.

23 Prior to the 1972 amendments, the EEOC did not have authority to file suit; if the Commission failed to reach a settlement, then private lawsuits were the only remaining remedy outside of pattern-or-practice suits by the Attorney General.

"See 42 U.S.C. $\$ 2000 \mathrm{e}-5(\mathrm{f})$ (1976).

so 472 F.2d at $1149-50$.

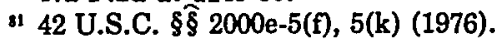

82 Id. § $2000 e-5(f)(1)$.

${ }^{83} \mathrm{Id}$.

8s This was the conclusion reached by the District of Columbia Circuit in Sears, 581 F.2d at 947-48, and the Seventh Circuit in Burlington Northern, 582 F.2d at 1101. 
the same reasons that support private settlement negotiations. $\mathrm{He}$ may hope to avoid the expense and trouble of litigation, and he may hope to achieve a result more favorable than that the courts might reach. The employer has an incentive to provide extensive information about hiring practices for use in the discussions: only from an informed view of the present position can a realistic remedy be fashioned. In addition, an employer may be induced to settle the charges by the hope of avoiding unfavorable publicity since if settlement is reached, the employer's identity is never revealed to the public. ${ }^{85}$ In the Sears case, for example, the company compiled an extensive and expensive statistical analysis concerning all of its 420,000 employees and supplied the EEOC with up-to-date information concerning its affirmative action program..$^{86}$ None of this information would have been supplied had it not been for the negotiation process: ${ }^{87}$ the EEOC would have been relegated to its powerful, but nevertheless cumbersome and time-consuming, powers of investigation.

The prospect that conciliation information may be released to aggrieved employees for use in lawsuits against the employer may inhibit the employer in providing such potentially damaging evidence to the EEOC. Congress apparently recognized this prospect when it provided that conciliation information could not be used as evidence in subsequent proceedings. ${ }^{88}$ Mere insulation from use as evidence, however, is a shallow protection if the EEOC can release the information to employees who will use it in framing their complaints and discovery requests. An analogy might be drawn to admissions made by a party during private settlement negotiations. Since allowing the opposing party to use admissions or offers would inhibit communication during negotiations, and thus discourage settlement, the general rule is that such admissions are inadmissible. ${ }^{89}$ The parallel policy of encouraging Title VII conciliation would

${ }^{85}$ EEOC decisions do not name the respondent; conciliation agreements are not released to the public. B. Schlei \& P. Grossman, supra note 6, at 816 .

88 581 F.2d at 944.

${ }^{87}$ Id. During the investigative phase, prior to the settlement discussions, the EEOC subpoenaed more limited information concerning approximately 30 percent of Sears's work force. Id. at 943-44. Some courts have held that the EEOC may not require employers to provide compilations of data. Georgia Power Co. v. EEOC, 295 F. Supp. 950 (N.D. Ga. 1968), aff'd, 412 F.2d 462 (5th Cir. 1969); U.S. Steel Corp. v. United States, 6 Fair Empl. Prac. Cas. 977 (W.D. Pa. 1973), aff'd, 487 F.2d 1396 (3d Cir. 1973). Contra, New Orleans Pub. Serv., Inc. v. Brown, 507 F.2d 160 (5th Cir. 1975); Local 104, Sheetmetal Workers v. EEOC, 303 F. Supp. 528 (N.D. Cal. 1969), aff'd in part, rev'd in part, 439 F.2d 237 (9th Cir. 1971).

${ }_{88} 42$ U.S.C. $\S 2000$ e-5(b) (1976).

89 Rule 408 of the Federal Rules of Evidence provides:

Evidence of (1) furnishing or offering or promising to furnish, or (2) accepting or 
similarly militate in favor of protecting conciliation information from further disclosure.

Disclosure of conciliation information to aggrieved employees also decreases the cost and trouble of filing a private suit, and may increase private litigation. As the Supreme Court has recognized, "the filing of a lawsuit might tend to deter efforts at conciliation," and "lack of success in the legal action could weaken the Commission's efforts to induce voluntary compliance."90 Since the employer's incentive to negotiate is largely to avoid the costs and uncertainties of litigation, his willingness to negotiate must necessarily decline if he faces large numbers of private lawsuits despite-indeed as a result of-his good-faith negotiation. If the suits are filed while conciliation is in process, the employer might be especially reluctant to agree to any settlement, which might appear to be an admission of guilt.

An additional reason for treating aggrieved employees as members of the public under section 706(b) is to ensure that the conciliation information not reach the general public through the employee. The employee may seek to generate popular support by selectively releasing unfavorable information about the employer to the press. The EEOC attempts to avoid this result by requiring aggrieved employees and their attornies to agree that the disclosures not be used for any purpose other than prosecuting a private claim and that it not be further disclosed except to the extent necessary for that purpose.91 The Fifth Circuit in Kessler apparently believed such an agreement to be adequate to protect against dissemination to the general public, ${ }^{, 2}$ but the District of Columbia Circuit in Sears

offering or promising to accept, a valuable consideration in compromising or attempting to compromise a claim which was disputed as to either validity or amount, is not admissible to prove liability for or invalidity of the claim or its amount. Evidence of conduct or statements made in compromise negotiations is likewise not admissible. This rule does not require exclusion when the evidence is offered for another purpose, such as proving bias or prejudice of a witness, negativing a contention of undue delay, or proving an effort to obstruct a criminal investigation or prosecution.

The purpose of this rule is to encourage settlements by enlarging the scope of the commonlaw privilege. Congress felt that the possibility of having things said and done in the course of settlement negotiations used as evidence in a subsequent proceeding was "an unjustifiable restraint upon efforts to negotiate settlements" because it hampered "free communications between the parties." S. REP. No. 1277, 93d Cong., 2d Sess. 10 (1974), reprinted in [1974] U.S. CoDE CONG. \& AD. NEws 7057. It is interesting to note that the EEOC strongly opposed this enlargement of the settlement privilege. H.R. REP. No. 650, 93rd Cong., 1st Sess. (1973).

* Johnson v. REA, Inc., 421 U.S. 454, 461 (1975).

"See Kessler, 468 F.2d at 29-30 (panel opinion) (quoting EEOC general counsel's memorandum to all EEOC field directors and field attornies, Sept. 15, 1970). See also EEOC Compl. Man. (CCH) \I 1785 (1977).

12472 F.2d at 1149 . 
described it as "obviously . . . not enforceable against those receiving information." ${ }_{93}$ That court termed disclosure to charging parties as "tantamount to distribution to the public at large." the practical, ${ }^{95}$ and perhaps constitutional, ${ }^{98}$ difficulties in restraining further dissemination of the information, enforcement of the policy of confidentiality may demand that employees not receive disclosures.

2. Effect of Disclosure of Investigatory Information. Disclosure of investigatory information to employees prior to their filing suit would be less disruptive of the Title VII conciliation scheme than disclosure of conciliation information. Since the EEOC is not dependent on the cooperation of the employer to obtain information under its investigative powers, the chilling effect on the information-gathering function would be less important. Since the aggrieved employee has the right to receive the investigatory information after filing suit, prior disclosure would effect only the timing, not the scope, of the information release. Nevertheless, the prior disclosure of investigatory information presents the identical problem of making further dissemination to the general public possible, and also may encourage private lawsuits that disrupt the conciliation process.

Although at least one court has argued that a provision denying an aggrieved employee access to investigatory information prior to filing suit may generate lawsuits by employees seeking such access, ${ }^{97}$ it seems more likely that the free discovery such disclosure entails would, on balance, increase private litigation. Under the statutory scheme, the aggrieved employee is required to wait 180 days after filing a charge with the EEOC before filing his own lawsuit. ${ }^{98}$ Even after this period, however, he has substantial incentive to wait for the EEOC to negotiate a settlement. If the settlement is satisfactory, the employee is spared the trouble and expense of litigation, including the expense of determining whether he has a meritorious claim. If aggrieved employees are given access to investigatory files during the course of the conciliation negotiations, it is much more likely that they will choose to file suit. Both the District of Colum-

${ }^{93} 581$ F.2d at 946.

s. Id. at 947 .

${ }^{95}$ As the Sears court pointed out, injunctive relief is difficult to obtain and would avail little once the aggrieved employee releases the information to the press. Id. at 946 .

${ }^{96}$ See In re Adele Halkin, 47 U.S.L.W. 2472 (D.C. Cir. Jan. 19, 1979); Radgers v. United States Steel Corp., 12 Fair Empl. Prac. Cas. 1526 (3d Cir. 1976).

${ }_{97}$ See the district court opinion in Sears, Roebuck \& Co. v. EEOC, 435 F. Supp. 751, 756 (D.D.C. 1977)

${ }^{98} 42$ U.S.C. $\$ 2000 \mathrm{e}-5(\mathrm{f})(1)$ (1976). 
bia $^{99}$ and the Seventh ${ }^{100}$ Circuits reached this conclusion, and decided that such early release is inconsistent with the policy of Title VII conciliation.

Consistency of interpretation as well demands that aggrieved employees be treated as members of the public for purposes of section 709(e). The word "public," used similarly in two parallel sections of the same statute, should be interpreted in the same way. ${ }^{101}$ Practical considerations support a consistent interpretation: if employees are treated as members of the "public" for purposes of conciliation information, but not as members of the "public" for purposes of investigatory information, then the distinction between the two types of information would take on increased importance. Since EEOC practice is to merge investigation and conciliation, such a distinction is impossible to draw with any precision. ${ }^{102}$ It must be drawn once an employee files suit and requests access to the investigatory file; the cases requiring such line drawing need not be multiplied by allowing access to the investigatory file to any aggrieved employee at any time. ${ }^{103}$ Moreover, since before the filing of a suit the employer would have no ready forum to challenge the distinction drawn between investigative and conciliation information, ${ }^{104}$ the danger that the EEOC might release conciliation information along with the investigative file is increased. The employer would effectively be at the mercy of the EEOC's interpretation of the distinction between conciliation and investigatory information. ${ }^{105}$

\section{Release of Information to Employers}

Once it is concluded that the word "public" includes aggrieved employees with regard to information supplied to the EEOC by the employer, or to the content of communications between the EEOC and the employer, consistency of logic and interpretation demands that the word be interpreted to include the employer with regard to information passing from aggrieved employees to the EEOC. The employer should not be granted access to communications between

" 581 F.2d at 946.

100582 F.2d at $1099-100$.

101 The courts are in agreement that sections 706(b) and 709(e) should be read the same way. Sears, 581 F.2d at 948; Kessler 472 F.2d at 1151.

102 See text and notes at notes 119-125 infra.

tos See, e.g., 581 F.2d at 949 n.11.

14 The employer would have to file suit to enjoin disclosure. See note 22 supra. If the employee had filed suit, it would be possible to obtain relief in that court by a motion for a protective order.

10s See note 122 infra. 
his employees and the Commission. ${ }^{108}$ It is not necessary, however, to provide protection for the EEOC itself against the information requests of employers. A common-sense interpretation of the word "public" would indicate that the employer is not a member of the "public" with regard to his own communications with the Commission.

The principal reason for employers to seek access to EEOC files is to prove that the Commission failed to negotiate in good faith. ${ }^{107}$ Such failure establishes a defense to an EEOC suit. ${ }^{108}$ The EEOC has argued, and some courts have agreed, that the contents of the conciliation files must be kept from the employer in order to avoid "chilling" the process of negotiation. ${ }^{109}$ This fear is misplaced. The employer's willingness to negotiate would in no way be diminished by his later ability to obtain access to the conciliation files. Nor would the Commission's willingness to negotiate be diminished: the Commission is required by law to undertake conciliation ${ }^{110}$ and has every practical reason to pursue that course. ${ }^{111}$ If the disclosure of conciliation files to employers were to have any effect on the conciliation process it might create an additional pressure on the EEOC to negotiate in good faith. Admittedly, the Commission might on occasion be embarrassed by disclosure of the conciliation file. Even this effect might, however, be lessened by inducing the employer not to disseminate the information to the general public. ${ }^{112}$ But the EEOC was not the intended beneficiary of the confidentiality pro-

106 Cf. EEOC v. Georgia Pac. Corp., 11 Fair Empl. Prac. Cas. 722, 724-25 (D. Ore. 1975) (employee's communications to the EEOC protected by attorney-client privilege). But see Charlotte-Mecklenburg Hosp. Auth. v. Perry, 571 F.2d 195 (4th Cir. 1978) (requiring release to employer under FOIA of statements by former employees in investigative file); EEOC v. St. Francis Community Hosp., 70 F.R.D. 592 (D.S.C. 1976) (ordering the release to the employer in discovery of letters from an aggrieved employee to the EEOC).

${ }_{107}$ See Haykel v. G.F.L. Furniture Leasing Co., 76 F.R.D. 386 (N.D. Ga. 1976); EEOC v. du Pont Co., 9 Fair Empl. Prac. Cas. 65 (W.D. Ky. 1974); EEOC v. Mississippi Federated Coop. Serv., 8 Fair Empl. Prac. Cas. 733 (S.D. Miss. 1974).

${ }_{103}$ See EEOC v. Raymond Metal Prods. Co., 530 F.2d 590 (4th Cir. 1970); 29 C.F.R. $\S$ 1601.24 (1978).

109 See, e.g., Haykel v. G.F.L. Furniture Leasing Co., 76 F.R.D. 386, 392 (N.D. Ga. 1976).

11042 U.S.C. $\S 2000 \mathrm{e}-5$ (b) (1976).

iI See text at note 76 supra.

112 In EEOC v. St. Francis Community Hosp., 70 F.R.D. 592 (D.S.C. 1976), the court released certain information related to conciliation to the employer on a discovery motion, but required him to agree not to disseminate the information to the general public, and not to use it as evidence. The practical difficulties in preventing a party from disseminating the information to the general public are described in note 95 supra. Ordinarily, the employer may be expected to prefer to avoid publicity; where the EEOC has been unfair to him, however, he might attempt to gain public support by selective release of parts of the conciliation file. 
visions. As one court said, these provisions are "obviously for the benefit of the charging party and the employer."113 Except when protection is needed for aggrieved employees, employers should be able to obtain access to the EEOC files.

\section{Problems of Application}

Having determined that aggrieved employees may only have access to EEOC investigatory information, which they may receive only after filing suit, the problem of defining the scope of that access must be confronted. Two difficulties are most important: whether an employee may gain access to portions of the investigatory file not directly related to his particular charge, and how to distinguish between conciliatory and investigatory information.

\section{A. Access to Investigatory Information}

An individual Title VII plaintiff might want access to the entire investigatory file concerning his employer for evidence that indirectly bolsters his case. More importantly, a Title VII plaintiff purporting to represent a class might seek access to files relating to all the members of his asserted class. Such access may be particularly important to defining the proper scope of the class and to identifying class members. In Burlington Northern, ${ }^{114}$ the Seventh Circuit addressed, and rejected, the claim of a class representative to the whole of an EEOC investigatory file before certification of the class. Limiting section 709(e) disclosure of investigatory information to that "directly relevant to individual charges of discrimination," 115 the court reasoned that broader disclosure would "undercut the effective performance of [the EEOC's] important responsibilities by providing self-styled class representatives with the mass of free discovery that could be expected to be found in the files of a national investigation by the Commission." 116 A similar result was reached by the district court in Mosley $v$. General Motors Corp., ${ }^{117}$ based on the theory that other class members were entitled to have their

${ }^{\text {t1 }}$ EEOC v. Mississippi Federated Coop. Serv., 8 Fair Empl. Prac. Cas. 733, 734 (S.D. Miss. 1974); accord, EEOC v. St. Francis Community Hosp., 70 F.R.D. 592 (D.S.C. 1976). Contra, Haykel v. G.F.L. Furniture Leasing Co., 76 F.R.D. 386 (N.D. Ga. 1976); EEOC v. E.I. du Pont de Nemours and Co., 9 Fair Empl. Prac. Cas. 65 (W.D. Ky. 1974).

"1" Burlington N., Inc. v. EEOC, 582 F.2d 1097 (7th Cir. 1978), cert. denied, 99 S. Ct. 1267 (1979).

11s Id. at 1101.

III Id.

11710 Fair Empl. Prac. Cas. 1442 (E.D. Mo. 1975). See also Parker v. EEOC, 10 Fair Empl. Prac. Cas. 1239, 1240-41 (D.D.C. 1975), aff'd, 534 F.2d 977 (D.C. Cir. 1976). 
charges and the investigatory files pertaining to them remain confidential until such time as the representative is certified.

Until the class is certified, the representative plaintiff has no right to or need for information related to the merits of the claims of other class members. The Supreme Court has recently held ${ }^{118}$ that, absent special circumstances, the representative plaintiff must bear the cost of identifying class members for purposes of notification. The Court specifically rejected the use of discovery to shift the burden to the defendant, reasoning that discovery is limited to disclosure of facts to be used to prove elements of the case. By analogy, the EEOC disclosure provisions should not be used to shift the burden of identifying class members. Until the class has been certified and the question of the merit of the claims of the absent class members becomes important, the investigatory files should be closed.

This result accords with the general policy of Title VII to promote EEOC conciliation and negotiation rather than private litigation. If a class action suit is pending, an employer will have little reason to pursue negotiation. Class suits, even more than individual suits, are disruptive of the conciliation process. Once the class is certified, and conciliation negotiations have broken down, release of investigatory information will do little damage. Until that time, class suits should not be encouraged by access to the EEOC files.

\section{B. Distinguishing Investigatory from Conciliation Information}

After filing suit, a Title VII plaintiff may receive information in the investigatory file on his charge; he may not receive information in the conciliation file. Yet the Commission has integrated the investigatory and conciliatory functions. No longer are the two types of file kept separate..$^{119}$ Accordingly, the courts and the EEOC face a difficult task in deciding which portions of the file on an employer may be disclosed. The Sears court ${ }^{120}$ recognized this problem and, although it did not have to decide the issue, noted that "any material given to the EEOC by Sears that the Commission could have obtained through the investigative mechanism of section 709(e)

"1s Oppenheimer Fund, Inc. v. Sanders, 437 U.S. 340 (1978). See also Eisen v. Carlisle \& Jacquelin, 417 U.S. 156 (1974).

"See text and notes at notes 17-20 supra. It has been held that the negotiations prior to investigation and determination of probable cause are protected by section $706(\mathrm{~b})$ to the same degree as conciliation negotiations. Parker v. EEOC, 534 F.2d 977 (D.C. Cir. 1976) (FOIA suit for release of predetermination settlement agreements; EEOC argued successfully that section 706(b) prohibited disclosure).

${ }_{120}$ Sears, Roebuck \& Co. v. EEOC, 581 F.2d 941 (D.C. Cir. 1978). 
might well be immune from the section 706(b) restriction on use at trial." 121

The EEOC responded by adopting a new regulation, providing that "[f]actual information obtained by the Commission during such informal endeavors, if such information is otherwise obtainable by the Commission under section 709 of Title VII, for disclosure purposes will be considered by the Commission as obtained during the investigatory process." 122 This regulation, however, goes too far. An investigator is almost always able to find a piece of evidence once he knows that it exists and where to look for it. Virtually any information provided by an employer during conciliation could potentially have been obtained by investigation. The regulation thus effectively eliminates the protection of section 706(b). The policy of encouraging conciliation demands a more restrained definition of investigatory information. The employer's decision to discuss his employment policies during conciliation should not be turned against him by reclassifying the information as "investigatory information" and making it available for use in future lawsuits.

Equally important, however, is facilitating the EEOC's use of informal predetermination negotiations. Rather than demand a strict adherence to the format of investigation followed by negotiation, it is more efficient to permit early discussions between the EEOC and the employer. An employer should not be permitted to insulate damaging evidence from disclosure by volunteering it during such negotiations. Information that the Commission could and would have obtained through investigation should be available to Title VII plaintiffs.

No bright-line test is available to distinguish conciliation from investigation information. A district court familiar with the methods of the EEOC is best able to make a reasonable accommodation between the competing parties. Several principles may be helpful. When an investigation is undertaken, and a probable cause determination made, it may generally be presumed that information disclosed after that determination is not investigatory, and should be protected. The line-drawing problem may thus be confined to information disclosed during the predetermination settlement negotiations. The problem may also be kept within reasonable bounds by strictly observing the limitation on access to information directly related to the individual plaintiff's charge. ${ }^{123}$ Thus, information con- 
cerning general practices of the firm, or practices in other areas, need not be divided into conciliation and investigation. ${ }^{124}$ Finally, the court may ease its burden by encouraging the EEOC and the employer to reach a private understanding at the beginning of the negotiations about the scope of protection for disclosures. In the past, the EEOC has manifested an unfortunate willingness to renege on assurances of confidentiality ${ }^{125}$ By requiring the Commission to honor such agreements, the courts could sometimes avoid the difficult and probably arbitrary task of distinguishing between the two types of information.

\section{ConcLusion}

Although informal negotiation and conciliation between the EEOC and private employers is the principal means of enforcing Title VII, the private lawsuit remains important for many individual employees. Such individuals often seek access to EEOC files in order to decide whether to sue and to support their claim once filed. Their access to the files is restricted by Title VII, however, because premature disclosure of investigatory information may interfere with conciliation endeavors, and disclosure of information voluntarily submitted by employers during negotiations may discourage candor and good faith conciliation. To promote conciliation, therefore, it is necessary that aggrieved employees be treated as members of the "public" for purposes of the confidentiality provisions of Title VII. In determining the proper scope of access to which an employee is entitled under the statute, the courts should be guided by the strong policy favoring conciliation to resolve employer-employee disputes.

L. G. Harter

124 Plaintiffs are, however, entitled to such general statistical information as would ordinarily have been obtained in investigation of the charge. Mosley v. General Motors Corp., 10 Fair Empl. Prac. Cas. 1442 (E.D. Mo. 1975).

${ }^{125}$ In Sears, for example, the EEOC repeatedly assured Sears that materials given to the Commission during negotiations would be kept confidential. Sears, Roebuck \& Co. v. EEOC, 435 F. Supp. 751, 760 (D.D.C. 1976), aff'd in part, rev'd in part, 581 F.2d 949 (D.C. Cir. 1978). Six months after the settlement discussions began, the EEOC promulgated regulations permitting access by charging parties, and subsequently notified Sears of its intention to release the files. 581 F.2d at 944 . 